\title{
English foreign language teaching anxiety of Indonesian pre-service teachers at undergraduate internship program
}

\author{
Huyi Intan Sari, Choiril Anwar* \\ English Education Study Program, College of Languages and Communication Science, \\ Universitas Islam Sultan Agung (UNISSULA) Semarang, Indonesia \\ *Corresponding Author \\ Email: choirilanwar@unissula.ac.id
}

Received:

30 January 2021
Revised:

20 July 2021
Accepted:

1 August 2021
Published:

31 August 2021

\begin{abstract}
Anxiety is a topic mostly investigated in the field of foreign language education. Unfortunately, the main focus of the studies on the aforementioned topic has primarily been provided in relation to anxiety suffered by students not teachers. Anxiety in speaking English while teaching has been proven to be a separate obstacle to the success of the language teaching and learning. This still happens to teachers who even have years of teaching experience. This study aims to investigate the English language teaching anxiety as experienced by the pre-service teacher at the department. The FLTA questionnaire consisting of 27 out of 45 items was adopted to collect data. Since this study was carried out during the COVID-19 pandemic, the questionnaire was distributed to the participants via email. The analysis was then made by implementing the qualitative descriptive approach and simple quantification to support the description. The results show that there were five factors of anxiety occur during the program. They were teaching inexperience, self-perception of language proficiency, fear of negative evaluation, lack of student's interest, and difficulty with time management. These findings are expected to become a reference for the efforts of developing an internship preparation program.
\end{abstract}

Keyword: inexperienced teaching; foreign language teaching anxiety; preservice teacher

\section{INTRODUCTION}

"I feel my English is not good enough for me to teach English". "I am worried that my students cannot understand my explanation because I use English." "I try to compose good and grammatically correct sentences, but I ended up screw up everything by making even worse mistakes." "My worriedness that I cannot speak well in English even makes me sweat a lot during classes." These are all comments made by the pre-service teachers during the casual conversation I made with them. As their field supervisor for the internship program, the comments of those pre-service teachers regarding their English language anxiety have certainly become my own concerns.

The phenomenon of non-native teachers and pre-service teachers experiencing language anxiety during teaching using the target language as 
Sari, H. I., \& Anwar, C. (2021). English foreign language teaching anxiety of Indonesian pre-service teachers at undergraduate internship program. EduLite: Journal of English Education, Literature, and Culture, 6 (2), 222-237. http://dx.doi.org/10.30659/e.6.2.222-237

the language of instruction in the language classroom is stated by Horwitz (1996 cited in Tum, 2012). As a never complete process of learning, the learning of foreign language has resulted in the fact that the teacher or preservice teacher is still a language learner himself, no matter what level of proficiency he may have reached in the target language. As a result, nonnative language teachers are forced to invest a lot of time, effort, and motivation in learning the target language in order to avoid anxiety itself. Facing such challenges, it is understandable if there are still many pre-service teachers and even experienced teachers who still experience a feeling of discomfort in teaching using the target language as the language of instruction in learning from time to time. Horwitz (1996) calls it chronic foreign language anxiety when such feelings of anxiety are frequent and recurring.

Language teacher emotions are a growing area of research that recognizes the emotional work of the profession; Therefore, Mercer and Gregersen (2020) state that language teaching, inherently emotional labor, can cause feelings of anger, frustration, disappointment, and anxiety as well as positive feelings such as happiness and joy. In line with research that focuses on emotional exertion language teachers, current research focuses on a particular teacher's emotion, foreign language teaching anxiety (FLTA). While much research has emerged on foreign language anxiety regarding identification, causes, and effects in the context of learning, FLTA has not attracted much attention from researchers (Tüm, 2015).

\section{Foreign language teaching anxiety (FLTA)}

The term anxiety in teaching foreign languages was first introduced by Horwitz (1996), which defines this as the feeling of anxiety experienced by non-native teachers in using a foreign language or target language as the language of instruction in the classroom due to the fact that they themselves are foreign language learners who still feel that they have not acquired adequate proficiency of the target language. This statement is supported eventually by Mercer (2018) who also argues that anxiety is actually a negative emotion of the teacher which is a result of his low mastery of the target language. Merç (2011) argues that FLTA has several triggering factors including classroom management, specific language teaching approaches, or problems related to power such as supervisor-teacher relationships. Aydin (2016) as concluded in Tum (2012) further defines FLTA in his qualitative study as "emotional and affective states felt by teachers as tensions caused by personal, perceptual, motivational and technical problems before, during and after teaching activities." Thus, different views about FLTA must exist and the factors causing the FLTA problem deserve to be investigated in the hope that a comprehensive understanding of this phenomenon can lead to conclusions about how FLTA is closely related to the success of the teaching and learning process in foreign language classes. Descriptive studies on this topic are expected to be able to produce a measuring instrument so that the components involved can show the potential and relationship between anxiety and the potential problems it causes.

Additionally, four previous studies were taken as the guide for the completion of this study. Those four studies range from the ones which focus on the correlation among contextual variables for EFL teachers and negative 
emotions, anxiety as causing teacher's stress, the manifestation of FLTA in foreign language education, and lastly, the validity and reliability of FLTA scale.

The first study was conducted by Khani and Mirzaee (2015) investigating the contextual variables that cause teacher's stress and negative emotion. It concluded that lack of social support, relations to colleagues and administrators, access to teaching equipment, and other stressors such as anger, frustration, and depression within the context of EFL teaching caused teacher's tension although their study failed to provide evidence of FLTA. The second study is the study which was aimed at finding out the factors that caused teacher's stress. This study by Wieczorek (2016) was a qualitative study which included teachers at various institutions as the participants. The result of the study resulted in the finding that the factors intriguing teacher's stress were to belong to two groups; general teacher stressors and specific stressors in EFL contexts. Factors such as heterogeneity of the target learner group, lack of device and teaching support, teaching for particular skills such as listening, speaking, grammar, and the implementation of new materials were related with teaching foreign language.

The two studies above underlie Aydin (2016) to carry out a qualitative study that specifically focuses on FLTA and how it manifests in foreign language teaching. The interview questionnaire as well as the writing of a reflective paper from 60 pre-service EFL teachers produced a temporal dimension of FLTA. In addition, his research also supports several previous findings such as technical problems in the classroom, low level language skills. On the other hand, it provides evidence for further FLTA sources such as fear of evaluation, experience in teaching, decreased teaching motivation, and motivation. The studies presented above indicate that there are several studies that directly address the issue of FLTA. In addition, several studies focused on negative teacher emotions and stressors for teachers which arguably could be generalized to FLTA.

To add, Aydin \& Ustuk (2020) conducted a study-this is then regarded as the third study-purporting to investigate the levels of FLTA among EFL teachers and if the levels of FLTA differ regarding the variables of gender, age, school levels and types, teaching experience in years, whether they are native or non-native speakers of English, the degree of graduation, and their nationalities. $156 \mathrm{EFL}$ teachers coming from various countries were taken as sample. A background questionnaire and the Foreign Language Teaching Anxiety Scale (FLTAS) were the tools for collecting the data. The background questionnaire surveyed participants' genders, ages, nationalities, countries where they worked, the types of schools they worked at, teaching experiences in years, graduation degrees, and native/non-nativeness. The FLTAS, designed by Aydın and Uştuk (2020), consisted of 27 items on a Likert scale (p.865) ranging from 1 to 5 . This study produces two main conclusions. First, from the broadest perspective, it could be argued that in-service EFL teachers experienced total FLTA at low levels. In particular, their self-perceptions of the language proficiency are not of the FLTA source. On the other hand, students' lack of interest in language classes is the cause of FLTA at moderate levels among EFL teachers, as well as fear of negative evaluations. In addition, time management problems cause low FLTA, while readiness for classes is a source 
Sari, H. I., \& Anwar, C. (2021). English foreign language teaching anxiety of Indonesian pre-service teachers at undergraduate internship program. EduLite: Journal of English Education, Literature, and Culture, 6 (2), 222-237. http://dx.doi.org/10.30659/e.6.2.222-237

at a moderate level. The second conclusion is gender, age, school level, type, teaching experience, and nativeness and non-nativeness varied significantly of FLTA rate, while the graduation rate does not differ according to FLTA. In terms of gender, male teachers felt more anxious than female teacher selfperception of language proficiency, fear of evaluation, inexperience, and time management, while the younger teacher worried the older one in terms of perceiving target language skills and fear of making mistakes (p. 865, Aydin and Usstuk (2020)). Whereas the fourth related previous study was conducted by Hartono and Maharani (2020). It was about English writing anxiety and the writing problems of Indonesia EFL learners. The results show that the students experienced a high level of English writing anxiety and cognitive anxiety was the students suffered most. Gender did not affect the level of anxiety and the students' perception of writing difficulties. Grammatical problems, vocabulary problem and insufficient writing practice became the three most mentioned-cause of anxiety.

Based on the results of the studies previously reviewed, we can comprehend that it is clear that there is a holistic view of FLTA. Regardless of the great interest in applied linguistics studies (Horwitz, 2010) and teacher emotion research that has recently gained understanding (Mercer, 2018), researchers have addressed the problem of FLTA in the context of countries focusing exclusively on it.

\section{Teaching practice}

Teaching practice is significant in training the pre-service teachers to improve their skills in teaching. This is a compulsory well-structured program at any teaching education programs. It purports to provide students with the experience in both developing teaching skills and evaluating the competence of teacher candidates in direct school setting. In my department, students are required to take the course of teaching practice/internship in the seventh semester. They are placed in schools for at least 2 months with the supervisors both from the lecturer and the supervising teachers. Thus, the program is actually the culmination point and the final point where the mutual relationship between the three main players: the supervising lecturer, the supervising teacher, and the pre-service teacher determines the quality of the soon-to-be teacher.

Teaching practice is the context in which pre-service teachers incorporate theory into practice by understanding and experiencing the practical reality of classroom and school (Richards \& Crookes, 1988). In addition, this is also reinforced by a statement (Tang, 2002) in Merç (2010) that this program occupies the highest level of cooperation between universities and other educational institutions. The main consideration in this program is how to make sure that the placement of the students at school can optimally provide them with significant experience in developing their teaching skills. It is argued by Paker (2000) that the department plays very important roles in placing the students in cooperated school. They must carefully choose schools of which the teachers are cooperative and successful aspirants of the target language and where teachers who work together are successful aspirants of the target language and master constructive teaching methodology at any levels. Both supervising lecturer and teachers must take into account that 
teacher students/pre-service need more pedagogical preparation and support to address them with FLTA support so that they will feel more confident with their own proficiency.

\section{METHOD}

Participant and scope of study

This study is aimed at investigating the English Foreign Language Teaching Anxiety (EFLTA) as experienced by the students of internship program involving 31 students of the seventh semester at the English Language Education Program of Universitas Islam Sultan Agung (UNISSULA) who joined the internship program at 4 schools in Semarang in the academic year $2020 / 2021$. These internship students had been equipped with teaching knowledge during their study from semester 1-5 including microteaching course which is simulations of teaching on campus with peer learning before joining the internship program.

\section{Instrument}

The FLTA questionnaire consisting of 27 out of 45 items as proposed by DeVellis (2016) was adopted to collect data. The 27 items were used since the validity and reliability were unquestionable based on the preliminary study conducted by Aydin and Ustuk (2020). They were intended to conduct a preliminary study to measure the validity and reliability of DeVellis' Foreign Language Anxiety Scale. The study involved 100 senior pre-service EFL teachers registered in a state university in Turkey. Consisting of 71 females and 29 males, in the Department of English Language Teaching at the research site, their age ranged from 21 to 28 . The participants had to experience teaching practice at least one semester criteria included at least one semester of teaching practice. All of the participants were senior preservice teachers who had their teaching practicum in the 2017-2018 academic year. In Turkey context, their practicum starts in the seventh semester and continues until their last semester of their undergraduate program. This means they had school experience including teaching practice at various state schools.

"The results of the study showed that FLTAS of 27 items (DeVellis, 2016) showed that a five-factor solution was found to account for $69.09 \%$ of the variance. The eigenvalues, the scree test, and the amount of variance explained showed that the FLTAS reached an optimal factor solution. The result also showed a high level of reliability according to the statistical tool developed by Kim and Kim (2004). Their tool consisted of 30 items and its reliability was calculated as .96; however, the calculation method was not detailed. The FLTAS is composed of fewer items $(n=27)$ and had a very similar reliability score (.95), which was calculated using Cronbach's Alpha. In the other FLTA scale constructed in Ipek's dissertation study (2006), the reliability co-efficient was calculated as .92 using Cronbach's alpha (Aydin \& Ustuk, 2020, p. 52).

Internal consistency reached by the study was categorized as high level. More specifically, the scale resulted in a five-factor solution based on preservice teachers' self-perceptions of foreign language proficiency, teaching inexperience, lack of student interest in classes, fear of negative evaluation by observers and students, and difficulties with time management. 
Sari, H. I., \& Anwar, C. (2021). English foreign language teaching anxiety of Indonesian pre-service teachers at undergraduate internship program. EduLite: Journal of English Education, Literature, and Culture, 6 (2), 222-237. http://dx.doi.org/10.30659/e.6.2.222-237

Since this study was carried out during the COVID-19 pandemic, the questionnaire was distributed to the participants via email. The data was collected in November 2020 after the program was completed. The analysis was then made by implementing the qualitative descriptive approach and simple quantification to support the description.

\section{RESULTS AND DISCUSSION}

As mentioned before that the study employed 27 items of FLTAS proven to be valid and reliable based on the preliminary study on it, following is the distribution of the items according to the five factors such as self-perceptions of foreign language proficiency, teaching inexperience, lack of student interest in classes, fear of negative evaluation by observers and students, and difficulties with time management. A Likert scale ranging from 1 to 5 (never $=$ 1 , rarely $=2$, sometimes $=3$, often $=4$, always $=5$ ) was utilized.

Table1. Distribution of Items

\begin{tabular}{|c|c|c|}
\hline Factors & $\begin{array}{l}\text { No. of } \\
\text { item }\end{array}$ & Statement \\
\hline \multirow{5}{*}{$\begin{array}{l}\text { Teaching } \\
\text { Inexperience }\end{array}$} & 1 & I feel worried before entering the classroom. \\
\hline & 2 & I feel anxious when I teach in the classroom. \\
\hline & 3 & $\begin{array}{l}\text { I think my lack of teaching experience makes me } \\
\text { nervous. }\end{array}$ \\
\hline & 4 & $\begin{array}{l}\text { I fear making mistakes while I am teaching in the } \\
\text { classroom }\end{array}$ \\
\hline & 5 & I feel tense when I am in the classroom. \\
\hline \multirow{12}{*}{$\begin{array}{c}\text { Self-perception of } \\
\text { language } \\
\text { proficiency }\end{array}$} & 6 & $\begin{array}{l}\text { Making mistakes while I am speaking makes me } \\
\text { feel embarrassed. }\end{array}$ \\
\hline & 7 & $\begin{array}{l}\text { I feel tense when I have difficulties teaching } \\
\text { grammar. }\end{array}$ \\
\hline & 8 & Unfamiliar topics in the textbook confuse me. \\
\hline & 9 & $\begin{array}{l}\text { Unexpected questions from students put } \\
\text { pressure on me. }\end{array}$ \\
\hline & 10 & $\begin{array}{l}\text { Pronunciation mistakes while I am speaking make } \\
\text { me nervous. }\end{array}$ \\
\hline & 11 & $\begin{array}{l}\text { I feel embarrassed when some students speak } \\
\text { English better than me. }\end{array}$ \\
\hline & 12 & $\begin{array}{l}\text { I feel embarrassed because I am not good at } \\
\text { English. }\end{array}$ \\
\hline & 13 & $\begin{array}{l}\text { When I feel anxious in class, I have difficulty using } \\
\text { English }\end{array}$ \\
\hline & 14 & $\begin{array}{l}\text { I am bothered when I have difficulty teaching the } \\
\text { cultural content of English }\end{array}$ \\
\hline & 15 & It makes me nervous to use English in classes. \\
\hline & 16 & $\begin{array}{l}\text { I feel embarrassed when I think that I am not } \\
\text { good at English. }\end{array}$ \\
\hline & 17 & I forget almost everything while I am teaching.. \\
\hline \multirow{3}{*}{$\begin{array}{l}\text { Fear of negative } \\
\text { evaluation }\end{array}$} & 18 & $\begin{array}{l}\text { I feel panicked when my mentor-teacher observes } \\
\text { me. }\end{array}$ \\
\hline & 19 & My mentors'observations make me nervous. \\
\hline & 20 & Students' negative comments about me make me \\
\hline
\end{tabular}




\begin{tabular}{lcl}
\hline & \multicolumn{2}{c}{ nervous. } \\
\hline & 21 & $\begin{array}{l}\text { I feel discouraged when students lose interest in } \\
\text { the activities. }\end{array}$ \\
\cline { 2 - 3 } $\begin{array}{c}\text { Lack of student's } \\
\text { interest }\end{array}$ & 22 & $\begin{array}{l}\text { I feel tense when students are not interested in } \\
\text { the activities. }\end{array}$ \\
\cline { 2 - 3 } & 23 & $\begin{array}{l}\text { I feel stressed when students do not participate } \\
\text { in the activities. }\end{array}$ \\
\hline & 24 & $\begin{array}{l}\text { I feel upset because my students are bad at } \\
\text { learning languages. }\end{array}$ \\
\hline $\begin{array}{c}\text { Difficulty with } \\
\text { time management }\end{array}$ & 25 & $\begin{array}{l}\text { I feel tense when I am not prepared for class. } \\
\text { I am nervous when I finish the activities before the } \\
\text { class ends. }\end{array}$ \\
\cline { 2 - 3 } & 27 & $\begin{array}{l}\text { I feel panicked when I cannot finish the class on } \\
\text { time. }\end{array}$ \\
\hline
\end{tabular}

Table 2. Distribution of answer

\begin{tabular}{|c|c|c|c|c|c|c|}
\hline \multirow{3}{*}{ NO } & \multirow{3}{*}{ Statements } & \multicolumn{5}{|c|}{ Scale percentage } \\
\hline & & never & rarely & $\begin{array}{c}\text { sometime } \\
\mathrm{s}\end{array}$ & often & always \\
\hline & & 1 & 2 & 3 & 4 & 5 \\
\hline 1 & $\begin{array}{l}\text { I feel worried before entering the } \\
\text { classroom. }\end{array}$ & 5 & 9 & 0 & 17 & 0 \\
\hline 2 & $\begin{array}{l}\text { I feel anxious when I teach in the } \\
\text { classroom. }\end{array}$ & 6 & 18 & 3 & 3 & 1 \\
\hline 3 & $\begin{array}{l}\text { I think my lack of teaching } \\
\text { experience makes me nervous. }\end{array}$ & 1 & 7 & 0 & 21 & 2 \\
\hline 4 & $\begin{array}{l}\text { I fear making mistakes while I am } \\
\text { teaching in the classroom }\end{array}$ & 3 & 3 & 0 & 22 & 3 \\
\hline 5 & $\begin{array}{l}\text { I feel tense when I am in the } \\
\text { classroom. }\end{array}$ & 0 & 19 & 2 & 10 & 0 \\
\hline 6 & $\begin{array}{l}\text { Making mistakes while I am } \\
\text { speaking makes me feel } \\
\text { embarrassed. }\end{array}$ & 0 & 11 & 1 & 18 & 1 \\
\hline 7 & $\begin{array}{l}\text { I feel tense when I have } \\
\text { difficulties teaching grammar. }\end{array}$ & 0 & 16 & 2 & 12 & 1 \\
\hline 8 & $\begin{array}{l}\text { Unfamiliar topics in the } \\
\text { textbook confuse me. }\end{array}$ & 3 & 8 & 2 & 17 & 1 \\
\hline 9 & $\begin{array}{l}\text { Unexpected questions from } \\
\text { students put pressure on me. }\end{array}$ & 3 & 17 & 2 & 8 & 1 \\
\hline 10 & $\begin{array}{l}\text { Pronunciation mistakes while } \\
\text { I am speaking make me } \\
\text { nervous. }\end{array}$ & 1 & 13 & 3 & 14 & 0 \\
\hline 11 & $\begin{array}{l}\text { I feel embarrassed when some } \\
\text { students speak English better } \\
\text { than me. }\end{array}$ & 0 & 8 & 4 & 15 & 4 \\
\hline 12 & $\begin{array}{l}\text { I feel embarrassed because I } \\
\text { am not good at English. }\end{array}$ & 1 & 9 & 5 & 13 & 3 \\
\hline 13 & $\begin{array}{l}\text { When I feel anxious in class, I } \\
\text { have difficulty using English }\end{array}$ & 1 & 18 & 3 & 8 & 1 \\
\hline 14 & $\begin{array}{l}\text { I am bothered when I have } \\
\text { difficulty teaching the cultural }\end{array}$ & 0 & 5 & 6 & 19 & 1 \\
\hline
\end{tabular}


Sari, H. I., \& Anwar, C. (2021). English foreign language teaching anxiety of Indonesian pre-service teachers at undergraduate internship program. EduLite: Journal of English Education, Literature, and Culture, 6 (2), 222-237. http://dx.doi.org/10.30659/e.6.2.222-237

\begin{tabular}{|c|c|c|c|c|c|c|}
\hline & content of English & & & & & \\
\hline 15 & $\begin{array}{l}\text { It makes me nervous to use } \\
\text { English in classes. }\end{array}$ & 2 & 19 & 3 & 7 & 0 \\
\hline 16 & $\begin{array}{l}\text { I feel embarrassed when I } \\
\text { think that I am not good at } \\
\text { English. }\end{array}$ & 1 & 12 & 2 & 15 & 1 \\
\hline 17 & $\begin{array}{l}\text { I forget almost everything while } \\
\text { I am teaching. }\end{array}$ & 10 & 19 & 0 & 2 & 0 \\
\hline 18 & $\begin{array}{l}\text { I feel panicked when my } \\
\text { mentor-teacher observes me. }\end{array}$ & 1 & 15 & 3 & 11 & 1 \\
\hline 19 & $\begin{array}{l}\text { My mentors' observations } \\
\text { make me nervous. }\end{array}$ & 1 & 12 & 1 & 16 & 1 \\
\hline 20 & $\begin{array}{l}\text { Students' negative comments } \\
\text { about me make me nervous. }\end{array}$ & 3 & 17 & 5 & 5 & 1 \\
\hline 21 & $\begin{array}{l}\text { I feel discouraged when } \\
\text { students lose interest in the } \\
\text { activities. }\end{array}$ & 10 & 10 & 2 & 8 & 1 \\
\hline 22 & $\begin{array}{l}\text { I feel tense when students are } \\
\text { not interested in the } \\
\text { activities. }\end{array}$ & 5 & 7 & 4 & 13 & 2 \\
\hline 23 & $\begin{array}{l}\text { I feel stressed when students } \\
\text { do not participate in the } \\
\text { activities. }\end{array}$ & 9 & 10 & 4 & 6 & 2 \\
\hline 24 & $\begin{array}{l}\text { I feel upset because my } \\
\text { students are bad at learning } \\
\text { languages. }\end{array}$ & 11 & 16 & 1 & 2 & 1 \\
\hline 25 & $\begin{array}{l}\text { I feel tense when I am not } \\
\text { prepared for class. }\end{array}$ & 1 & 6 & 3 & 20 & 1 \\
\hline 26 & $\begin{array}{l}\text { I am nervous when I finish the } \\
\text { activities before the class } \\
\text { ends. }\end{array}$ & 4 & 13 & 3 & 10 & 1 \\
\hline 27 & $\begin{array}{l}\text { I feel panicked when I cannot } \\
\text { finish the class on time. }\end{array}$ & 5 & 10 & 1 & 15 & 0 \\
\hline
\end{tabular}

Table 3. Percentage of answer

\begin{tabular}{|c|c|c|c|c|c|c|}
\hline \multirow{3}{*}{ Factors } & \multirow{3}{*}{$\begin{array}{c}\text { No. of } \\
\text { Statement }\end{array}$} & \multicolumn{5}{|c|}{ Mean of scale percentage } \\
\hline & & never & $\begin{array}{c}\text { rarel } \\
\mathrm{y}\end{array}$ & $\begin{array}{c}\text { sometime } \\
\mathrm{s}\end{array}$ & often & $\begin{array}{l}\text { alway } \\
\text { s }\end{array}$ \\
\hline & & 1 & 2 & 3 & 4 & 5 \\
\hline \multirow{10}{*}{ Teaching Inexperience } & \multirow[t]{2}{*}{1} & 16.1 & 29.0 & & 54.8 & \\
\hline & & 3 & 3 & 0.00 & 4 & 0.00 \\
\hline & \multirow[t]{2}{*}{2} & 19.3 & 58.0 & & & \\
\hline & & 5 & 6 & 9.68 & 9.68 & 3.23 \\
\hline & \multirow[t]{2}{*}{3} & & 22.5 & & 67.7 & \\
\hline & & 3.23 & 8 & 0.00 & 4 & 6.45 \\
\hline & \multirow[t]{2}{*}{4} & & & & 70.9 & \\
\hline & & 9.68 & 9.68 & 0.00 & 7 & 9.68 \\
\hline & \multirow[t]{2}{*}{5} & & 61.2 & & 32.2 & \\
\hline & & 0.00 & 9 & 6.45 & 6 & 0.00 \\
\hline \multicolumn{2}{|l|}{ Total mean } & 9.68 & $\begin{array}{c}36.1 \\
3\end{array}$ & 3.23 & $\begin{array}{c}47.1 \\
0\end{array}$ & 3.87 \\
\hline \multirow{2}{*}{$\begin{array}{c}\text { Self-perception of } \\
\text { language proficiency }\end{array}$} & \multirow[t]{2}{*}{6} & & 35.4 & & 58.0 & \\
\hline & & 0.00 & 8 & 3.23 & 6 & 3.23 \\
\hline
\end{tabular}




\begin{tabular}{|c|c|c|c|c|c|c|}
\hline & \multirow[t]{2}{*}{7} & \multicolumn{3}{|c|}{51.6} & \multicolumn{2}{|l|}{38.7} \\
\hline & & 0.00 & 1 & 6.45 & 1 & 3.23 \\
\hline & \multirow[t]{2}{*}{8} & \multicolumn{3}{|c|}{25.8} & 54.8 & \multirow[b]{2}{*}{3.23} \\
\hline & & 9.68 & 1 & 6.45 & 4 & \\
\hline & \multirow[t]{2}{*}{9} & \multicolumn{3}{|c|}{54.8} & 25.8 & \multirow[b]{2}{*}{3.23} \\
\hline & & 9.68 & 4 & 6.45 & 1 & \\
\hline & \multirow[t]{2}{*}{10} & \multicolumn{3}{|c|}{41.9} & 45.1 & \multirow[b]{2}{*}{0.00} \\
\hline & & 3.23 & 4 & 9.68 & 6 & \\
\hline & \multirow[t]{2}{*}{11} & \multicolumn{3}{|c|}{25.8} & 48.3 & \multirow[b]{2}{*}{12.90} \\
\hline & & 0.00 & 1 & 12.90 & 9 & \\
\hline & \multirow[t]{2}{*}{12} & \multicolumn{3}{|c|}{29.0} & 41.9 & \multirow[b]{2}{*}{9.68} \\
\hline & & 3.23 & 3 & 16.13 & 4 & \\
\hline & \multirow[t]{2}{*}{13} & \multicolumn{3}{|c|}{58.0} & 25.8 & \multirow[b]{2}{*}{3.23} \\
\hline & & 3.23 & 6 & 9.68 & 1 & \\
\hline & 14 & & 16.1 & & 61.2 & \\
\hline & & 0.00 & 3 & 19.35 & 9 & 3.23 \\
\hline & 15 & & 61.2 & & 22.5 & \\
\hline & & 6.45 & 9 & 9.68 & 8 & 0.00 \\
\hline & 16 & & 38.7 & & 48.3 & \\
\hline & & 3.23 & 1 & 6.45 & 9 & 3.23 \\
\hline & 17 & 32.2 & 61.2 & & & \\
\hline & & 6 & 9 & 0.00 & 6.45 & 0.00 \\
\hline Total mean & & & 41.6 & & 39.7 & \\
\hline & & 5.91 & 7 & 8.87 & 8 & 3.76 \\
\hline & 18 & & 48.3 & & 35.4 & \\
\hline & & 3.23 & 9 & 9.68 & 8 & 3.23 \\
\hline Fear of negative & 19 & & 38.7 & & 51.6 & \\
\hline evaluation & & 3.23 & 1 & 3.23 & 1 & 3.23 \\
\hline & 20 & & 54.8 & & 16.1 & \\
\hline & & 9.68 & 4 & 16.13 & 3 & 3.23 \\
\hline Total mean & & & 47.3 & & 34.4 & \\
\hline & & 5.38 & 1 & 9.68 & 1 & 3.23 \\
\hline & 21 & 32.2 & 32.2 & & 25.8 & \\
\hline & & 6 & 6 & 6.45 & 1 & 3.23 \\
\hline & 22 & 16.1 & 22.5 & & 41.9 & \\
\hline Lack of student's interest & & 3 & 8 & 12.90 & 4 & 6.45 \\
\hline Lack or students interest & 23 & 29.0 & 32.2 & & 19.3 & \\
\hline & & 3 & 6 & 12.90 & 5 & 6.45 \\
\hline & 24 & 35.4 & 51.6 & & & \\
\hline & & 8 & 1 & 3.23 & 6.45 & 3.23 \\
\hline Total mean & & 28.2 & 34.6 & & 23.3 & \\
\hline & & 3 & 8 & 8.87 & 9 & 4.84 \\
\hline & 25 & & 19.3 & & 64.5 & \\
\hline & & 3.23 & 5 & 9.68 & 2 & 3.23 \\
\hline Difficulty with time & 26 & 12.9 & 41.9 & & 32.2 & \\
\hline management & & 0 & 4 & 9.68 & 6 & 3.23 \\
\hline & 27 & 16.1 & 32.2 & & 48.3 & \\
\hline & & 3 & 6 & 3.23 & 9 & 0.00 \\
\hline Total mean & & 10.7 & 31.1 & & 48.3 & \\
\hline & & 5 & 8 & 7.53 & 9 & 2.15 \\
\hline
\end{tabular}

Description of the result

Factor 1: Teaching inexperience 
Sari, H. I., \& Anwar, C. (2021). English foreign language teaching anxiety of Indonesian pre-service teachers at undergraduate internship program. EduLite: Journal of English Education, Literature, and Culture, 6 (2), 222-237. http://dx.doi.org/10.30659/e.6.2.222-237

Based on the result as showed in Table 3, we can draw a conclusion that the highest percentage for the Teaching Inexperience factor is on the scale of "often", which is $47.10 \%$. Almost half of the pre-service teacher at the department experienced anxiety during the internship program causing by their inexperience in teaching. Most of the students felt worried when entering the class, although it was online class. The lack of teaching experience, the fear of making mistake while teaching, and tension during teaching also caused the high rate of anxiety to most of the pre-service teachers.

Most people will feel uncomfortable with new situations hence inexperienced teachers will feel fear or worriedness during class as they have never been in that kind of new situation and the pressure given to the profession of teaching by the society. They are demanded to be a good role model for the students, mastering teaching materials, and to be able to deliver these materials well in a way that the students would enjoy the learning process with them. Inexperienced teachers have not possessed adequate and accurate strategies to deal with the anxiety and the pressure during teaching. This is because most of the strategies are only possible to be acquired through a long period of time.

\section{Factor 2: Self-perception of language proficiency}

Table 3 shows that the highest percentage, $58 \%$, is on the "often" scale, meaning that the factor of self-perception of English proficiency does cause much anxiety to the pre-service teachers. However, there are several phenomena that need to be comprehensively described as the factor carries several aspects.

First, most of the pre-service teachers experienced anxiety when they had to explain unfamiliar topics. Unfamiliar topics turned out to be something confusing to them. This goes in line with the fact that their inexperience fails to enable them to find accurate strategy to avoid confusion when dealing with unfamiliar topics. Second, another fact shows that more than half of the students considered their low proficiency of English caused embarrassment to them. Even worse, they felt embarrassed when finding out that their students' English happened to be better than theirs. Lastly, the students also responded that they felt bothered when having difficulty teaching English cultural content. This does make sense since the understanding of English cultural content is the result of students' efforts in developing their proficiency in English. We cannot understand a language without understanding its culture, can we?

\section{Factor 3: Fear of negative evaluation}

Throughout the teaching practicum ideally the tutor teachers are supposed to monitor the teaching practice of the pre-service teacher all the time. However, in reality, this rarely happens. Tutor teachers rarely watch closely what the pre-service teachers are doing in the class. When they approve the pre-service teacher's lesson plan, he would feel that they would receive positive evaluation for their actual teaching. This is the reason why most of the pre-service teachers responded that they rarely experience the fear of negative evaluation. This is the reason why students do not worry much about poor evaluations. 
Moreover, teaching is done online where there is no direct physical interaction between pre-service teachers and tutor teachers.

Another possible reason why the students mostly responded that they rarely experienced fear of negative evaluation is that they might feel that their own proficiency in English were better than that of the tutor teachers. They knew that they did not have much experience in teaching so they were ready for criticism and welcomed constructive feedback. On the other hand, there were some students experiencing anxiety more often over negative evaluation coming from the tutor teachers. It is possible that one of the factors why this happened is because the pre-service teachers failed building good personal relationship with the tutor teachers. Even worse, the online teaching practicum put additional obstacle to the aforementioned condition. Therefore, when the tutor teacher seems to maintain a formal atmosphere, the interns cannot stop trying to build closer relationships with him. Senior tutor teachers usually keep their distance from the interns and this leads to the perception that the teacher is too strict, difficult, and is considered to have a high standard of assessment of the intern's performance. These eventually bring about another tension to the students and are assumed to cause stress while performing teaching.

\section{Factor 4: Lack of student's interest}

For this factor, students' comments vary substantially. Some responded that they never felt bothered even though the students gave less attention to their teaching, did not show any interest in the activities they created, and performed low learning during class. Online teaching practicum puts another stress on the pre-service teacher as it is more difficult to monitor the attentiveness of the students to the teaching itself. The online teaching rarely happened interactively. The pre-service teachers only sent the materials, gave short explanation to the students, and eventually assigned the students to do exercises by themselves with lack of feedbacks.

One of the non-technical factors why the pre-service teacher were lessbothered with the student's lack of interest is that they only cared about how to get the score without concerning if their teaching was valuable or not. The absence of the tutor teacher during class is another factor that leads to the pre-service teacher's ignorance whether the students are really learning or not. Technical factors also contribute to the above less-motivating teaching and learning process. Signal strength of the internet connection usually fails to maintain stable connection. Many of the students use mobile phones instead of computers which actually provide narrower vision to easily read the materials presented by the pre-service teachers. What also happens is when the ongoing teaching and learning suddenly stop because the students are running out of data quota.

\section{Factor 5: Difficulty with time management}

From the result we can conclude that most of the pre-service teachers experienced anxiety dealing with time management. The admitted that they often felt the stress when the failed finishing the teaching on time or on the contrary had to finish earlier while the time was still available for them to continue. The first mentioned happened when they provided materials more 
Sari, H. I., \& Anwar, C. (2021). English foreign language teaching anxiety of Indonesian pre-service teachers at undergraduate internship program. EduLite: Journal of English Education, Literature, and Culture, 6 (2), 222-237. http://dx.doi.org/10.30659/e.6.2.222-237

abundant than the time allocated for them. The second occurred because they provided less material and ran out of ideas to buy some time until the time allocated was out.

Both phenomena, the excess and the lack of teaching duration, are caused by the failure to see the focus on the targeted skills that the pre-service teachers are intended to improve. They failed to actually allocate the time for each teaching steps that they decided to perform. It is a time management nightmare for the pre-service teachers when they cannot successfully provide a well-defined teaching procedure on daily basis. This may cause the occurrence of the ideal teaching and learning environment.

\section{Description of Written Comments}

The instrument of the study is a close-ended questionnaire with the last part is the column for the respondents to write their own description of anxiety they experienced all through the internship program. 18 comments were chosen and considered to be representative enough to describe the topic of this study. The table below is the compilation of those 18 comments.

Table 4. Written student's comments

Describe the anxiety that you have experienced during the Internship Program...

The anxieties I face in teaching English are:

1. I feel less confident when speaking English quickly. The fear of wrong grammar worries me.

2. I worry when I find students who still don't understand the material I teach. So I will contact the student concerned and ask what material he did not understand.

3. I am worried when there are students who get less than the standard score for assignments / tests.

4. There was an unexpected question from the student which in my opinion was a difficult question. I don't want to give arbitrary answers to my students because I think they deserve the right knowledge, not carelessly.

5. I still find it difficult to speak English at a fast tempo.

6. I have lack of self-confidence when speaking English

7. I feel worried if there are students who still do not understand the material if I explain in full English even though the tempo is quite slow.

8. The thing that makes me anxious in teaching is when the material being taught is accompanied by a lack of student interest in learning so that learning feels boring for students.

9. I feel anxious when I don't really understand the material to be presented.

10. Insufficient teaching preparation / completeness made me anxious.

11. I am anxious when the students do not fully understand the material I am presenting.

12. I feel more stressed when knowing that my teaching is being evaluated. My tutor teacher demands a perfect performance.

13. I'm worried that my tutor teacher would give me bad comments in front of the students.

14. I am worried if my English is not proficient, especially when I have some students who are cleverer and more talented in English. With this, I need to improve my knowledge and skills a lot again.

15. My anxiety during teaching English is that I am afraid to forget the words in English when I try to explain to my students, because even though I am still an apprenticeship student or teacher I really want to give my best for my students. 
16. Getting nervous on the first day is a normal. I was feeling nervous at some events on the beginning days. After first or second days, I knew how to face the moment. I learned a lot in every meeting. Practice makes perfect! When I first taught me there must be anxiety and restlessness. Because I don't know about the atmosphere and characteristics of the students. But after I tried to teach, I came to know and know the atmosphere of the class. Each time I finish teaching, I evaluate myself what I need to improve on. So I learn more in each meeting, and can improve any of my shortcomings

17. My anxiety sometimes arose before I started teaching. At the beginning of the class, the anxiety was still felt, but as the teaching activities progressed, I felt more relaxed. My feelings of anxiety also usually arise when I feel that my teaching preparation is still lacking, and also when a lecturer or tutor is conducting a classroom action assessment.

18. In my opinion, feeling anxious about teaching students in high school apprenticeship is a very normal thing, especially what I face is active and creative students like the students I taught during my internship at SMA 2 Semarang. It sometimes makes me feel anxious if they are less interested in attending my classes. Either because the material is boring with the methods I use or due to other factors such as distance learning during a pandemic like this one is currently happening. However, I realized that my shortcomings during the internship made me more motivated to do even better things in the future when I become an educator.

The comments above indicate that the five factors that cause teaching anxiety do exist despite the fact that teaching practices are held online. It turns out that the pre-service teachers feel this anxiety even though the scope of direct interaction between interns, teacher tutors and students is very limited and might be said to be far from ideal.

The comments also show that there are some students who can overcome this anxiety, even indirectly implying that the anxiety is considered as a trigger for enthusiasm and motivation to try to show better performance in teaching. The foreign language barrier from the side of the pre-service teacher during the teaching program is indeed a challenge for them to take great efforts to develop. Is this challenge a motivation to continue to improve foreign language skills or even just a discouraging thing? It is the responsibility of the lecturers in the study program to continue to improve the quality of foreign language teaching and learning that can equip graduates with a high level of foreign language proficiency and be able to compete in the global scope.

The pre-service teachers' anxiety was caused more by the worry that they could not fulfill the expectations of the tutor teachers and the students themselves. Their students hope to get a model speaker with good English, a teacher who can explain difficult concepts clearly and easily understood, someone who can inspire and motivate them, and who can create a fun and meaningful atmosphere of learning English. Tutor teachers put too much hope that the pre-service teachers can make proper teaching administration and be able to convey curriculum content properly. The campus and the school also expect the same from the interns. Unfortunately, they consider it a burden that discourages their spirits. Heavy burdens and lack of skills cause anxiety. This is actually the root cause of the pre-service teachers' nervousness when they teach in class. 
Sari, H. I., \& Anwar, C. (2021). English foreign language teaching anxiety of Indonesian pre-service teachers at undergraduate internship program. EduLite: Journal of English Education, Literature, and Culture, 6 (2), 222-237. http://dx.doi.org/10.30659/e.6.2.222-237

\section{CONCLUSION}

This conclusion provides evidence related to the existing potential factors that root to become the trigger to teaching anxiety in the foreign language teaching contexts. The readers should note that this study only presents a surface result of the anxiety that the pre-service students of the internship program experienced throughout the program, taking 2 month of time duration. Presenting the preliminary results of the FLTAS is a part of the research process. Obviously, the findings of this study are very limited to the research context, and these limitations can be addressed in future studies. Another limitation is that the participants in this study were only 31 pre-service teachers whose teaching experience was mostly limited to their teaching practicum. The lack of experience might have influenced the results. Therefore, it is very important to use the FLTAS with a wider group of foreign language teachers who have more varied backgrounds in terms of experience. The inclusion of native speakers of foreign language is also an important consideration in carrying out future research in order to investigate whether their insight could help researchers gain a better understanding of FLTA.

The limitation of this study is a strong reason for future research to be conducted, that is to include descriptive studies to further discuss the effectiveness of FLTAS with a larger sample that is also representative of the pre-service teacher population on a global scale and with more complex discussions with underlying multicultural factors leading to the occurrence of such anxiety. Therefore, the results of this preliminary research report can be developed and investigated further.

Several implications can also be drawn from the findings of this study. First, because inexperienced teaching is an important factor underlying FLTA, school teaching members must take all necessary precautions when working with less experienced teachers and the department should provide more subjects included in the curriculum that actually train the students skill in teaching through direct peer-teaching activities. Second, the self-perception of language proficiency requires the student teachers to take more great efforts in improving their mastery of the language in order to overcome self-distrust which leads to anxiety. Third because fear of negative evaluations was found to be a source of FLTA at moderate levels, foreign language pre-service teachers should give attention to enhancing their social impressions among tutor teachers and school members.

In conclusion, to achieve the goal of teaching English in the EFL context, the characteristics of a qualified English teacher must include sufficient proficiency in four language skills (listening, speaking, reading, and writing). Those who graduate with a Bachelor of English Language Education are required to show it with certainty. Effective foreign language teachers also need to have knowledge of the learner's psychological development and of innovative and up-to-date teaching techniques. They must be able to provide or even create modern teaching aids and platforms that can provide motivating and inspiring fun teaching that enables students to develop their own potential. 


\section{ACKNOWLEDGMENT}

The researchers feel thankful to the Research and Community Service Institute of Universitas Islam Sultan Agung Semarang for supporting us with the funding and chance to undertake this internal research. In addition, we also like to thank the dean of language and communication science faculty and all lecturers giving some suggestion to make some betterments for this article.

\section{REFERENCES}

Aydin, S., \& Ustuk, O. (2020). The foreign language teaching anxiety scale: Preliminary tests of validity and reliability. Journal of Language and Education, 6(2), 44-55. https://doi.org/10.17323/JLE.2020.10083

Aydın, S. (2016). A qualitative research on foreign language teaching anxiety. The Qualitative Report, 21(4), 629- 642.

DeVellis, R. F. (2016). Scale development: Theory and applications (4th ed.). Sage Publications.

Hartono, H., \& Maharani, M. M. (2020). English writing anxiety and the writing problems of Indonesia EFL learners. Advances in Social Science, Education and Humanities Research, 409, https://doi.org/10.2991/assehr.k.200225.111

Horwitz, E. K. (1996). Even teachers get the blues: Recognizing and alleviating language teachers' feelings of foreign language anxiety. Foreign Language Annals, 29(3), 365-372. https://doi.org/10.1111/j.1944-9720.1996.tb01248.x

Horwitz, E. K. (2010). Foreign and second language anxiety. Language Teaching, 43(2), 154-167. https://doi. org/10.1017/s026144480999036x

İpek, H. (2006). Foreign language teaching anxiety (Unpublished doctoral dissertation), Anadolu University.

İpek, H. (2016). A qualitative study on foreign language teaching anxiety. Journal of Qualitative Research in Education, 4(3), 1-14. https://doi.org/10.14689/issn.2148-2624.1.4c3s5m

Khani, R., \& Mirzaee, A. (2015). How do self-efficacy, contextual variables and stressors affect teacher burnout in an EFL context? Educational Psychology, 35(1), 93-109. https://doi.org/10.1080/01443410.2014.981510

Merç, A. (2010). Foreign language student teacher anxiety (Unpublished doctoral dissertation), Anadolu University.

Merç, Ali. (2011). Sources of foreign language student teacher anxiety: A qualitative inquiry. Turkish Online Journal of Qualitative Inquiry, 2(4), 80-94. https://doi.org/10.17569/tojqi.08990

Mercer, S. (2018). Psychology for language learning: Spare a thought for the teacher. Language Teaching, 51(4), 504-525. https://doi.org/10.1017/s0261444817000258

Mercer, S., \& Gregersen, T. (2020). Teacher wellbeing. Oxford University Press.

Paker, T. (2011). Student teacher anxiety related to the teaching practicum. Eurasian Journal of Education Research, (42), 207-224 
Sari, H. I., \& Anwar, C. (2021). English foreign language teaching anxiety of Indonesian pre-service teachers at undergraduate internship program. EduLite: Journal of English Education, Literature, and Culture, 6 (2), 222-237. http://dx.doi.org/10.30659/e.6.2.222-237

Richards, J. C., \& Crookes, G. (1988). The Practicum in TESOL. TESOL Quarterly, 22(1), 9. https://doi.org/10.2307/3587059

Tüm, D. O. (2012). Feelings of language anxiety amongst non-native student teachers. Procedia - Social and Behavioral Sciences, 47, 2055-2059. https://doi.org/10.1016/j.sbspro.2012.06.948

Wieczorek, A. L. (2016). High inhibitions and low self-esteem as factors contributing to foreign language teacher stress. In D. Gabrys-Barker \& D. Gałajda (Eds.), Positive psychology perspectives on foreign language learning and teaching (pp. 231-248). https://doi.org/10.1007/978-3-319-32954-3_13

Conflict of Interest Statement: The authors declare that the research was conducted in the absence of any commercial or financial relationships that could be construed as a potential conflict of interest.

Copyright (C) 2021 Sari and Anwar. This is an open-access article distributed under the terms of the Creative Commons Attribution License (CC BY). The use, distribution or reproduction in other forums is permitted, provided the original author(s) and the copyright owner(s) are credited and that the original publication in this journal is cited, in accordance with accepted academic practice. No use, distribution or reproduction is permitted which does not comply with these terms. 